\title{
PERANAN MICROSOFT WINDOWS DALAM SISTEM OPERASI PERANGKAT LUNAK KOMPUTER
}

\author{
Nur Shakila Amanda \\ Pendidikan Matematika Fakultas Ilmu Tarbiyah dan Keguruan Universitas Islam Negeri \\ Sumatera Utara, Uinsu. \\ Email : Shakilaamanda99@gmail.com
}

\begin{abstract}
Computers have experienced very rapid development and cannot be compared again like they used to when they were first introduced. Not only for storing data, performing Mathematical operations, and running Applications, but in line with the increasing performance of devices and software, the facilities are becoming increasingly developed in various aspects of life at this time. One of the most important parts of a computer system is the operating system.The use of the Windows 7 operating system is still in the top position during 2015 with maximum users above 50\%. Meanwhile, Windows 8 to 10, although experiencing positive progress (up), but the increase is not stable. Its function is to control the programs that have been given from the software, hardware and other systems that are on the computer. Being the latest windows from computers, Windows 10 already has many advantages over previous windows and further refines the devices that have been used so that it is easier for users to use this latest program and can maximize it properly.
\end{abstract}

Keywords: Microsoft; Windows ; Operating system

\begin{abstract}
Abstrak
Komputer sudah mengalami perkembangan yang begitu pesat dan tidak bisa dibandingkan lagi seperti dulu ketika pertama kali diperkenalkan. Tidak hanya untuk menyimpan data-data, melakukan operasi Matematika, dan menjalankan Aplikasi, namun sejalan dengan semakin meningkatnya performa perangkat maupun software, sarananya menjadi semakin berkembang dalam berbagai semua aspek kehidupan pada saat ini. Salah satunya bagian terpenting dalam sistem komputer adalah sistem operasi. Penggunaan sistem operasi windows 7 masih berada pada posisi teratas selama tahun 2015 dengan pengguna maksimal diatas 50\%. Sedangkan selanjutnya, windows 8 hingga 10, meskipun mengalami perkembangan kemajuan yang positif (naik), namun kenikannya tidaklah stabil. Fungsinya adalah untuk mengontrol programprogram yang telah diberikan dari perangkat lunak, perangkat keras dan sistem lainnya yang berada di dalam komputer. Menjadi windows terbaru dari komputer, windows 10 telah memiliki banyak keunggulan dari windows-windows sebelumnya dan semakin menyempurnakan perangkat-perangkat yang telah digunakan sehingga para pengguna semakin mudah untuk memakai program terbaru ini dan semakin bisa memaksimalkannya dengan tepat.
\end{abstract}

Kata Kunci : Microsoft ; Windows ; Sistem operasi

\section{PENDAHULUAN}


Sistem operasi merupakan peranan penting dalam sebuah perangkat keras seperti laptop maupun komputer. Sistem yang ada hari ini merupakan suatu hasil perubahan yang begitu di pengaruhi oleh perkembangan komputer selama bertahuntahun lamanya. Windows yaitu salah satu dari banyaknya sistem operasi yang pernah ada hingga saat ini. Windows sudah mempunyai banyak perkembangan untuk membuat sistem yang sesuai untuk masyarakat. Bagian windows yang paling banyak digunakan saat ini yaitu windows 7 , 8 dan windows 10. Dari ketiga bagian tersebut memiliki kelebihan dan kekurangannya masing-masing sehingga pembeli bingung memilihnya.

Perangkat lunak sangat berfungsi untuk pengolaan perangkat keras pada komputer dan dapat menyediakan layanan yang belum terdapat pada komputer. Serta banyaknya pengoperasian yang digunakan pengguna membuat perangkat ini satu sama lain dapat bekerja dengan baik, sehingga dapat menghasilkan hasil yang sempurna. pengoperasian komputer tidak mengandalkan pada perangkat keras saja namun terhadap beberapa komponen lainnya, yaitu perangkat keras (hardware), perangkat lunak (software) dan pengguna (brainware).

Banyak masalah yang dihadapi oleh pengguna sistem operasi windows saat ini yaitu bingung dalam memilih sistem operasi yang mana yang bagus untuk dipakai dalam kehidupan sehari-hari. Yaitu contohnya sangat banyak perangkatperangkat dan sistem yang banyak digunakan bagi kalangan pengguna komputer. Seperti pada kejadian windows ini, masih banyak laptop yang bukan zamannya masih memakai windows 7 dan bagi orang-orang yang memiliki gaya hidup dikalangan atas bisa membeli laptop yang lebih terjangkau yaitu sudah memiliki sistem windows 10 . Hal tersebut membuat perbandingan yang sangat jelas dan nyata bagi para pengguna komputer.

Dengan membandingkan antara windows 7 , 8 dan windows 10. karena itu dibuatkanlah penelitian untuk sistem operasi windows yang sesuai dan yang paling banyak diminati oleh konsumen / pembeli dan lebih tepatnya pada kalangan pelajar dan mahasiswa. Berdasarkan hal-hal sebelumnya, tujuan dan beberapa hasil kajian memudahkan dalam pemilihan sistem operasi maupun dengan membandingkan seluruh bagian yang ada dari setiap jenis sistem operasi windows tersebut.

\section{KAJIAN LITERATUR}

\section{Pengertian Sistem}

Sistem menurut para ahli, dapat diartikan sebagai berikut ; menurut Ludwig Von Bartalanfy, sistem merupakan seperangkat unsur yang saling terikat dan saling berhubungan. Alasannya karena pada banyaknya sistem tersebut membuat ketergantungan antar sistem satu dengan yang lainnya. Sistem memiliki banyak perangkat yang membuat pengoperasiannya dapat berjalan sebagaimana mestinya.

Sistem terdiri dari tiga unsur yaitu : input (masukan), proses dan output (pengeluaran). Input merupakan pemasukan dari data-data yang akan dikirim melalui perangkat operasi komputer, proses yaitu berjalannya datadata yang sudah dikirim melalui unsut input 
yang akan dipergunakan oleh pengguna sebagai media pengerjaan umum seperti membuat data, pengaplikasian suatu operasi dan masih banyak lagi. Sedangkan output yaitu pengeluaran aatau jika ada virus-viru sudh terlalu banyak maka harus dikeluarkan dengan cara meng upgrade ulang aplikasi menghilangkan virus-virus ttersebut. 3 unsur tersebut sudah sangan membuat pengguna keringanan dan tidak kesusahan dalam pengerjaan perangkat lunak ataupun perangkat keras komputer.

Berikut ini dikemukakan sifat dari sistem sebagaimana merujuk defenisi yang sudah dijelaskan diatas, yaitu :

1. Tujuan sistem, merupakan hal yang akan dicapai padasistem komputer melalui perangkat-perangkat yangada.

2. Batas sistem, adalah hal yang membatasi antara satu dengan yang lainnya

3. Subsistem, adalah suatu komponen dari sistem yang berada pada dalam jaringan komputer maupun yang dapat terlihat dan digunakan seperti perangkat / aplikasi yang sudah sering digunakan.

\section{Pengertian Komputer}

Komputer adalah sebuah benda atau alat elektronik yang akan terhubung melalui energi listrik dimana di dalamnya terdapat banyak sistem atau jaringan-jaringan perangkat lunak dan keras, terdapat beberapa menu atau aplikasi serta banyaknya web yang dapat dikunjungi. Komputer mempunyai banyak perangkatperangkat didalamnya, seperti yang terkenal dari dulu hingga sekarang yaitu microsoft word, microsoft excel, serta beberapa perangkat lunak dan keras agar bisa terhubung ke internet atau terhubung ke jaringan-jaringan yang lain.
Adapun pengertian komputer menurut para ahli yaitu :

Menurut C.Hamacher, Z.G, Vranesic dan Z.G.Zaky, komputer didefenisikan sebagai sebuah alat elektronik yang dapat mengoperasikan data dengan cepat dan teratur agar dapat mengoperasikan data secara maksimal.

Kesimpulan dari beberapa defenisi komputer tersebut adalah :

- Komputer pada awalnya yaitu hanyalah sebuah perangkat elektronik yang bisa terhubung melalui aliran listrik.

- Komputer membutuhkan perangkat bwaan, perangkat lunak, dan perangkat keras yang merupakan bawaan dari sebuah alat komputer untuk dapat bekerja melalui gerakan ketikan seperti mesin cepat dan serbaguna.

- Komputer dapat menyajikan detail sebuah informasi serta dapat mengedit sebuah tulisan agar lebih banyak manfaatnya dan dapat berguna bagi banyak orang.

Seperti yang sudah dijelakan diatas, masih banyak lagi manfaatdari komputer yaitu : 1) Dapat mengubah font dalam tulisan agar bisa lebih mempercantik bagi pembacanya. 2) Membantu pekerja, mahasiswa ataupun anak sekolah dalam membuat pekerjaan rumah/tugas ataupun dapat membantu banyak pekerjaan seperti orang yang bekerja dalam perkantoran dibidang ketikmengetik.

3) Komputer juga menyediakan aplikasi agar jika kita bingung membuka sebuah data melalui handphone, komputerdapat membuka aplikasi tersebut. 
4) Membantu pengguna untuk mendapat banyaknya hiburan melalu web yang sudah tersedia maupun yang akan dicari.

5) Dapat melakukan koneksi melalu jaringan sesama komputer walaupun memiliki merk yang berbeda-beda.

\section{Pengertian Sistem Operasi}

Sistem Operasi adalah sebuah program yang menyediakan antar muka yang lebih mudah bagi pengguna untuk mengakses perangkat keras dalam perkembangan sebuah program. Atau juga bisa dibilang bahwa, sistem operasi juga bisa menghubungkan antara perangkat lunak suatu pengaplikasian sebuah komputer dengan perangkat keras, sehingga perangkat lunak aplikasi itu bisa mengakses perangkat keras dengan berjalan sempurna. Tanenbaum mempertegas fungsi sistem operasi sebagai resourceTTmanager yaitu mengizinkan multiple program pada waktu yang sama, mengelola dan melindungi memori dan sumberdaya lainnya.

Menurut Computer Hope, sistem operasi adalah software yang dipasangkan pada hard drive sebuah komputer, sehingga hardware dapat "berkomunikasi" dan bekerja dengan software di dalam perangkat tersebut.

Sistem operasi mengalami perkembangan yang sangat pesat, yang dapat dibagi kedalam empat generasi, yaitu :

1. Generasi Pertama (1945-1955)

Generasi awal/pertama adalah permulan berkembangnya sistem komputasi elektroniik. Hal ini membuat awal masyarakat yang sudah memiliki komputer atau penggunanya dapat dengan cepat menghitung atau mengumpulkan data lebih cepat daripada sebelumnya.

2. Generasi Kedua (1955-1965)

Generasi kedua diperkenalkan melalui Batch Processing System, yaiu pekerjaan yang dilakukan secara tertata dan berkelompok sehingga bisa menghasilkan suatu pengoperasian yang dapat digunakan dengan kelebihannya sendiri.

3. Generasi Ketiga (1965-1980)

Pada generasi ini perkembangan sistem operasi dikembangkan agardapat langsung melayani beberapa perangkat sekaligus untuk mengoperasikan datadata yang sudah tersedia. Manfaatnya lebih baik daripada generasi-generasi sebelumnya.

4. Generasi Keempat (Pasca 1980an)

Saat ini, sistem operasi dipergunakan untuk jaringan komputer dimana pemakai sudah banyak mengetahui bagaimanakah cara penggunannya hingga pemakaiannya. Perangkatnya pun sudah banyak yang lebih maksimal dan sangat memadai. Tak jarang banyak orang yang kagum dengan sistem operasi ini.

\section{Pengertian Windows}

Windows merupakan sistem operasi buatan microsoft, dimana sistem operasi ini menyediakan perangkat yang berbeda agar lebih mudah digunakan oleh banyaknya pengguna di seluruh kalangan. Dengan adanya windows, pengguna komputer tidak lagi kesusahan seperti padazaman dahulu karena padasaat windows dibuat sistem jaringannya menjadi lebih kekinian agardapat membantu mengoperasikan data dengan cepat dan langsung teratur.

\section{BAHAN DAN METODE}


1. Pengamatan Langsung (Observasi)

Penulis melakukan penvaharian langsung dan mengamati langsung tentang operasi windows, perpustakaan dan internet. Dimana banyaknya tulisan yang penulis baca membuat beberapa ringkasan agar ditumpahkan kedalam artikel ini.

2. Angket (Kuesioner)

Penulis membuat beberapa data angket atau tulisan sebuah pertanyann yang akan disebarkan ke beberapa orang untuk dijawab dan dikembalikan lagi kepada penulis. Beberapa orang tersebut ialah orang tua serta teman-teman terdekat penulis.

3. Studi Pustaka

$\begin{array}{lrr}\text { Setelah } & \text { melalukan } & \text { observasi } \\ \text { (pengmatan } & \text { langsung), } & \text { angket }\end{array}$ (kuesioner) penulis akan mencari lagi beberapa tuliisan seperti buku tentang komputer, jurnal ataupun artikel agar menambah pustaka tulisan artikel ini.

\section{HASIL DAN PEMBAHASAN}

Hasil dan pembahasan yang akan dibuat oleh penulis dalam artikel ini yaitu tentang windows yang sudah keluar dalam komputer dari dulu hingga sekarang yaitu windos 7 , windows 8 dan yang terbaru yaitu windows 10. Berikut merupakan pembahasan dari sistem operasi wondows.

\section{Sistem Operasi Microsoft Windows}

\section{Windows 7}

Tidak seperti sebelumnya yang lebih banyak mengeluarkan fitur atau perangkat baru, windows 7 lebih fokus pada pengembangan dasar windows, dengan tujuan agar lebih memperbaiki perangkatperangkat sebelumnya yaitu Windows
Vista. Presentase windows ini padatahun keluarnya sangat banyak digunakan karena sudah bagus dalam sebuah sistem operasi hanya saja masih banyak yang harus diperbaiki.

Beberapa aplikasi yang sangat memungkinkan dan memiliki ke standart an khsus pada windows 7 ini dapat dilihat dari fiture awal timeline saat membuka komputer/laptop pengguna. Menurut penulis karena windows ini merupakan pertama kalinya dilakukan perubahan membuatnya lebih gampang dan mudah untuk belajar memakainya. Banyak nya aplikasi dan tetap bisa membuka sebanyakbanyak nya membuat fitur windows 7 tersebut banyak digemari oleh orang-orang penggunanya terdahulu.

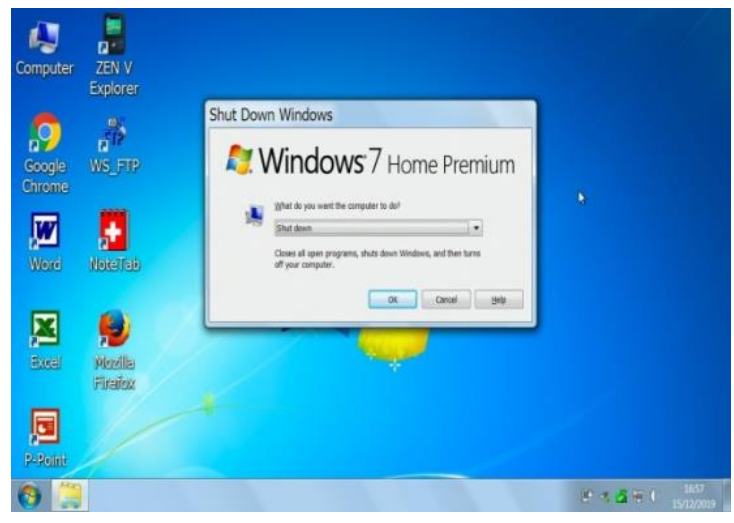

Rekomendasi Spesifikasi Minimal Windows 7

\begin{tabular}{|c|c|c|}
\hline Arksitektur & 32-hit & 64-bit \\
\hline $\begin{array}{l}\text { Kecepatan unit } \\
\text { pengolah pusat }\end{array}$ & $1 \mathrm{GHz} 32 \mathrm{bit} \mathrm{CPU}$ & $1 \mathrm{GHz}$ 64-bit CPU \\
\hline $\begin{array}{l}\text { Memori Akses } \\
\text { Acak(RAMi) }\end{array}$ & 1 GB of RAM & 2 GB of RAM \\
\hline Kartu Grafis & \multicolumn{2}{|c|}{$\begin{array}{l}\text { Dukungan DirectX } 9 \text { prosesor grafis dengan WODM Driver } \\
\text { Model } 1.0 \text { (Untuk Windows Aero) }\end{array}$} \\
\hline Cakram Keras(HDD) & Memori tersedia 16 GB & Memori tersedia 20 GiB \\
\hline Cakram optik & \multicolumn{2}{|c|}{ DVD drive (untuk instalasi dari media DVD) } \\
\hline
\end{tabular}




\section{Windows 8}

Microsoft secararesmi merilis windows 8 pada26 oktober 2012 bersamaan dengan peluncuran perdana komputer yang menggunakan windows 8 . Windows 8 adalah nama dari versi terbaru Microsoft Windows, serangkaian sistem operasi yang diproduksi oleh microsoft untuk digunakan pada komputer pribadi, termasuk komputer rumah dan bisnis, laptop, notebook, tablet PC, server dan PC pusat media.

Pada beberapa pengguna yang sebelumnya memakai fitur pada windows 8 , sebenarnya sedikit mirip. Tetapi pada windows ini lebih banyak tersedia beberapa sistem perangkat yang membuat pengguna bisa dengan leluasa mengapresiasikan ide atau gagasan yang akan dicantumkan dalam komuternya. Hal tersebut membuat banyaknya manfaat yang diberikan pada windows 8 ini. Dan sangat memberi fungsi tersendiri kepada khayalak ramai.

Windows 8 tersedia dalam empat edisi :satu bernama hanya windows 8 , ditujukan untuk konsumen mainstream. Windows 8 pro berisi fitur tambahan ditujukan untuk pengguna ahli dan lingkungan profesional. Windows 8 enterprise mengandung fitur tambahan ditujukan kepada lingkungan bisnis, dan hanya tersedia melalui plesensian volume. Windows 8 ini sudah sangat memiliki banyak kemajuan di dalam perangkat-perangkatnya dan sistem operasinya dalam menyajikan sistem atau data-data yang akan digunakan bagi para penggunanya. Hal tersebut membuat pengguna lebih dapat terpuaskan dari windows sebelumnya apalagi dengan sitem nya yang sudah terperbaharui menjadi lebih aman.

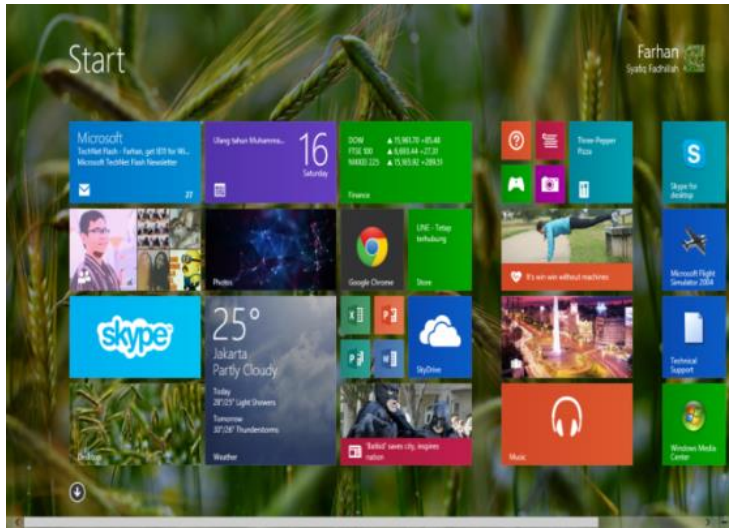

\section{Rekomendasi Spesifikasi Minimal Windows 8}

\begin{tabular}{|c|c|c|}
\hline Arsitethur & X86 (32. bitt) & $\times 86.64(64.610$ it $)$ \\
\hline Prosesor & x.861 GHz & $\times 86.641 \mathrm{GHz}$ \\
\hline Memori|(RAll| & $16 B$ & $2 G B$ \\
\hline Kartu grafils & \multicolumn{2}{|c|}{ 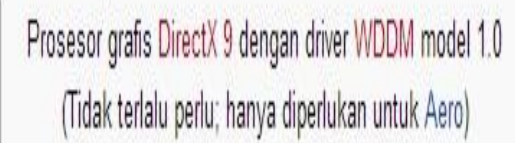 } \\
\hline Ruang Kosong HOL & $16 G 8$ & dtau ledih, JKk RAM diatas 1669 \\
\hline
\end{tabular}

\section{Windows `10}

Sistem operasi yang di perkenalkan pada tahun 2014 dan dirilis pada tahun 2015 ini sangat menggemparkan dunia. Apalagi pagi para penyuka perangkat-perangkat terbaru dari komputer serta merknya yang beragam membuat mereka berlomba-lomba untuk mendapatkannya. Windows 10 ini dibuat untuk antarmka pribadi dari para menggunanya di masing-masing tempat dan wilayah. Banyaknya penggemar yang ingin mencoba sistem operasi ini membuatnya banyak digandrungi karena memiliki banyak perangkat-perangkat baru serta sistemnya seperti di upgrade ulang sehingga pemakaiannya sangat mudah dimengerti. Apalagi sedikitnya aktivitas virus yang tidak tersebar. Oleh karena itu windows 10 pada zaman sekarang lebih 
banyak dipakai karena banyak memiliki kelebihannya tersendiri.

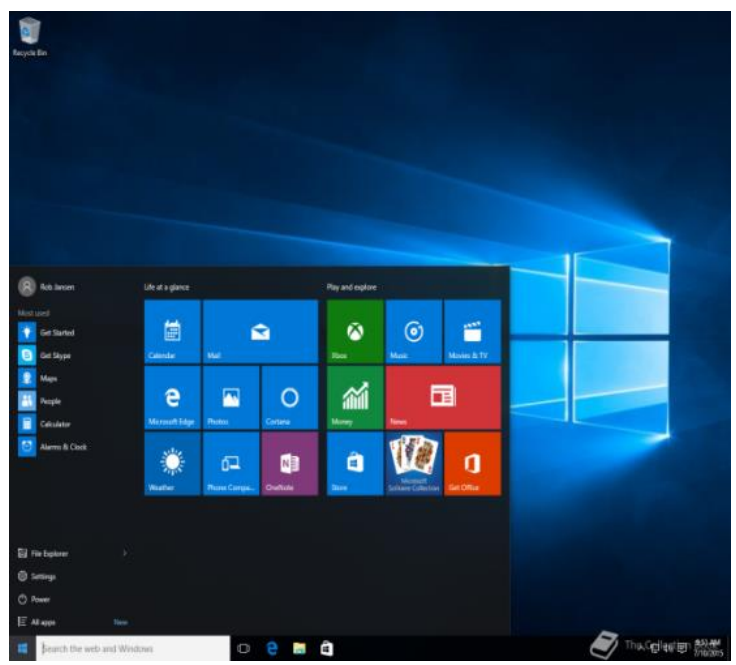

Spesifikasi Minimum Windows 10 Untuk PC dan Laptop

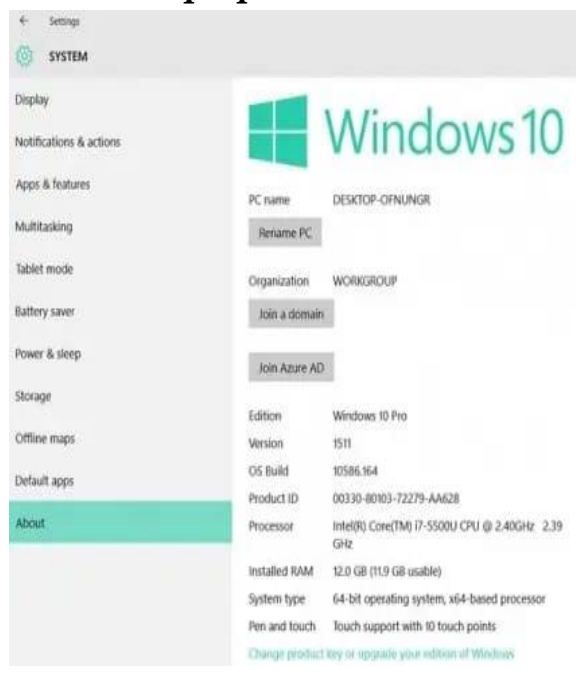

1) RAM : 1 GB untuk 32-bit dan 2 GB untuk 64-bit

2) Prosesor : $1 \mathrm{GHz}$ atau $\mathrm{SoC}$

3) Hard Disk : 16 GB untuk 32-bit dan 20 GB untuk 64-bit

4) Display : 800x600

5) Graphics Card : DirectX 9 atau ditasnya dengan driver WDDM 1.0

6) Akun Microsoft

7) Koneksi Internet

\section{Keamanan Sistem Operasi}

Informasi adalah aset, sebagaimana asetaaset penting lainnya, yang esensial terhadap bisnis organisasi dan oleh sebab itu perlu dilindungi dengan sepantasnya. Lebih penting lagi karena makin bertambahnya interkoneksi lingkungan bisnis. Sebagai dampak dari meningkatnya konektivitas, informasi diekspos terhadap ancaman dan vulnerability yang semakin hari semakin meningkat.

Pada windows 10 itu karena mempunyai aset pribadi yang sangat dijaga ketat oleh sistem operasinya yang terbaru membuat sistem keamanannya sangat dipergunakan untuk data pribadi saja. Sebagaimana banyaknya pengguna yang kadang mempunyai data-data yang sangat privasi sangat menguntungkna memakai sistem operasi ini. Apalagi windows ini juga sangat berperang penting dakam seluruh perangkat-perangkat atau semua operasi yang berada di dalam komputer kita. Seperti pengalaman penulis sendiri ketika memakai windows 7 , sangat sering terjadinya restart ulang membuat data-data penting yang seharusnya disimpan sedemikian rupa seketika hilang begitu saja tidak tahu kemana arahnya. Hal-hal seperti itulah yang terkadang membuat banyaknya pengguna sedikit fustasi ketika data-data yang ingin disimpan hilang.

Tetapi pada windows 10 ini penulis tidak pernah melihat kejadian seperti dahulu lagi, dimana semua sistemnya sudah tertata rapi agar pengguna baru akan lebih nyaman memakainya.

Garfinkel mengemukakan bahwa keamanan komputer melinkupi empat aspek, yaitu : privacyTTintegrity, Ttauthentication dan availability. Selain itu masih ada dua aspek lain yang juga sering dibahas dalam 
kaitannya dengan electroniccommerce yaitu access control dan non repudiation.

\section{KESIMPULAN}

Berdasarkan analisis hasil penelitian dan pembahasan yang penulis sudah jabarkan sedemikian rupa, bahwasannya windows 7 masih dibilang merupakan awal dari sitem operasi tersebut dimana masih banyak memiliki kekurangan antar pengguna yang membuat banyak otang masih inget meng upgrade ulang, lalu pada windows 8 mungkin masih sedikit sama dengan windows 7 dimana juga masih banyak halhal yang harus diperbaiki contohnya pada perangkat lunak dan perangkat kerasnya. Sedangkan untuk windows 10 terlalu banyak pengupdate ulang untuk setiap komputer, laptop ataupun notebook. Hal tersebut membuat pengguna merasa agak kesusahan dalam mengubah windows 10 ini dan adapun cara-caratertentu dalam pengaplikasian di dalam OS. Dari pengujian yang dilakukan peneliti dalam penelitian ini, maka perbandingan antara sistem operasi windows 7 , windows 8 dan windows 10 menghasilkan bahwa windows 8 lebih aman dibandingkan windows 7 dan windows 10, dikarenakan adanya fitur Windows Defender yang merupakan gabungan antara WindowsDfefender pada windows 7 dan MicrosoftSecurity Essensials.

Sebenarnya juga masih banyak perkembangan antara 3 windows tersebut yaitu windows 7,8 dan windows 10 . Dimana masing-masing diantaranya masih banyak memiliki kekurangan dan takpula dibalik kekurangannya pun ada kelebihannya masing-masing. contohnya pada windows 7 pasti karena merupakan awalan dari beberapa windows setelahnya, seperti masih banyak sistem operasinya yang belum stabil dan belum terancang dengan bagus dan sempurna. Lalu pada windows 8 karena kenaikan sistem dan operasi pasti banyak menggeser perangkatperangkat dan banyak terganti dari windows 7 sebelumnya. Adanya virusvirus pada komputer juga dapat menyebabkan kurangnya kinerja pada operasi komputer yang dapt menyebabkan kerusakan parah. Dan yang terakhir pada windows 10 mungkin lebih sempurna daropada windows 7 dan 8 , tetapi tak jarang juga pengguna windows 10 banyak yang mengeluh karena masih adanya virus yang tersebar didalam perangkat komputer tersebut.

Bagi orang-orang pengguna windoss 7 sebaiknya mendownload atau menginstal aplikasi untuk mengurangi banyaknya virus pada komputer, tetapi jika cara tersebut seharusnya penggunak memang harus mengganti windows. Untuk windows 8 hampir sama dengan windows 7 harus mengupgrade ulang aplikasi pembasmi virus untuk lebih menyempurnakan sistem operasi dan Untuk pengamatan selanjutnya agar kemungkinan dapat lebih diuji keamanan pada windows 10 dengan membandingkannya juga dengan sistem sebelumnya atau dengan sistem operasi selain windows, misalnya linux. Jadi sebenarnya para windows ini sudah sangat bagus di era pertama kali mereka muncul. Tetapi karena zaman semakin berkembang dan semakin banyaknya orang-orang melakukan pengamatan, hal tersebut membuat adanya perluasan ide-ide yang belum dicapai sebelumnya.

Adapun saran penulis kepada banyaknya orang yang ikut berpartisipasi dalam pembuatan berbagai perangkat dan sistem 
operasi, serta pembuat komputer/laptop yang setiap tahunnya memiliki merk terbaru dengan fitur terbaru pula. masih banyak orang yang memaki fiturfiturrendah dan merk komputer sebagaimana mereka mampunya, tetapi tak kadang pula kita merasakan bahwa fitur terbarulah yang paling bagus. Menurut saya lebih baik jangan tergesa-gesa dalam membuat suatu karya baru, karena suatu karya walaupun harus menempuh waktu yang sangat jauh hingga berpuluh-puluh tahun akan berguna jika semua orang dapat merasakan manfaatnya.

\section{REFERENSI}

Suharyanto, Cosmas Eko.2016.Analisis Komparatif Sistem Keamanan Windows 7 Dan Windows 8,Vol.4 Nomor 1.Halaman 1-21.

Yahfizam, Yahfizham (2013) Model Penerapan Etika Teknologi Informasi pada Organisasi (Perusahaan), Vol 07.No.02. Halaman 76-87.

Yahfizham,Yahfizham (2016) Sistem Informasi Berbasis Komputer Sebagai pendukung Keputusan Pemilihan Pejabat Menggunakan Metode AHP.Iqra' : Jurnal Perpustakaan dan Informasi,08(01).pp.28-39.ISSN 2442-8175.

Sulistyowati, Daning Nur,DKK.2018.Sistem Pendukung Keputusan Pemilihan Sistem Operasi Windows Pada Dekstop Dengan Menggunakan Metode Analytical Hierarchy
Process, Vol.3.No.2.Halaman 175180.

Nelfira,Diana Silvia.2015.Rancang Bangun Aplikasi Pembelajaran Sistem Operasi Windows Pada Matakuliah Sistem Operasi Di STMIK Indonesia Padang Berbasis Multimedia

Interaktif,V2.i2.Halaman 182-189.

Maulana,Yana Iqbal.2015.Perancangan Perangkat Lunak Sistem Informasi Pendataan Guru Dan Sekolah (Sindaru) Pada Dinas Pendidikan Kota Tangerang Selatan, Volume 13 No.1.Halaman 21-27.

Surya, Ibnu.2015.Kebutuhan Perangkat Lunak Untuk Aplikasi Data Mining, Vol.03.No.02.Halaman 233-240.

Rokhman, Moh Miftakhur.2018.Pelatihan Pemanfaatan Microsoft Office PadaStaf Pengajar Di SMPLBN (Sekolah Menengah Pertama Luar Biasa Negeri) Kota Malang,Vol.1,No1.Halaman 4-9.

Maisyarah, Rahmah.Efektifitas Penerapan Aplikasi Microsoft Office Pada Pembelajaran Akuntansi Di Kelas X SMK. Halaman 1-12.

Agustina, Rini, DKK.2019.Pelatihan Internet Dan Program Microsoft Office Untuk Membantu Administrasi Di Kelurahan Mojosari Kecamatan Lowokwaru Kota Malang.Volume.2,No.2.Halaman 129-144. 
Rosyidah,Masayu.DKK.2015.Pelatihan

Penggunaan Microsoft Office Bagi

Guru SMP Al-Hamidiyah

Palembang,Volume.01,No.01.Hala

man 1-20. 